\title{
IV. Alutițen.
}

\section{Jit das Töten eines Eranten wildes während der Shonjeit verboten?}

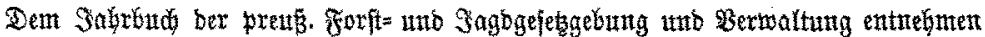

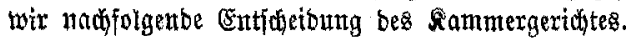

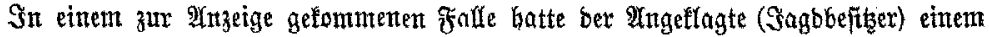

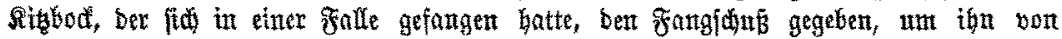
feinen Dutaren łu befreien. Die Straffammet Gatte ben Ângetlagten freigefproden. Das Mammergeridt hat aber berurteilt, weil ber auf baŝ Töten bes Bilbes geridtete

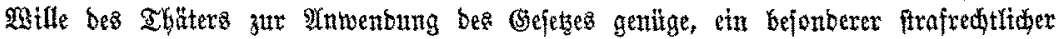

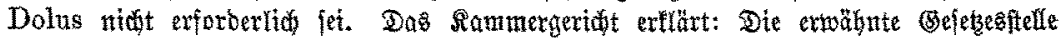

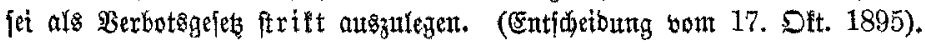

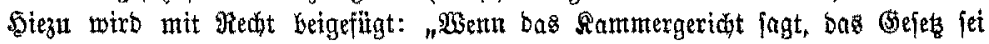

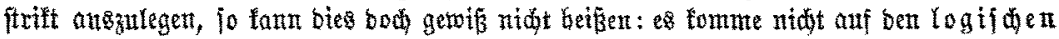

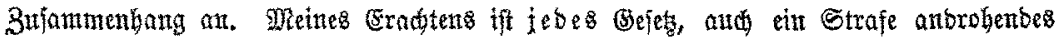
Derbotagefes, wor allett Ditrgen mit bett Mitteln bes gefult attoutlegen!"

\section{Dertilgung Ser Waulwurisgrille.}

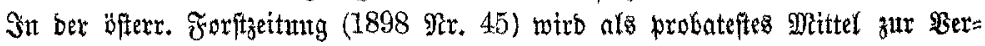
tilgutrg ber in Saatbeeten oft fo läftigen Maulwurfgrgrillen bas Bergifiten berfelben empfoblen. Die zu berwenbenben Giftbrofen wexben bergeftell, inbem man $0,25 \mathrm{~kg}$

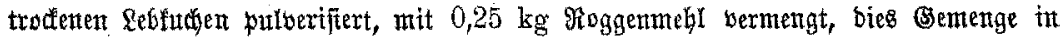

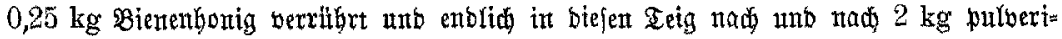

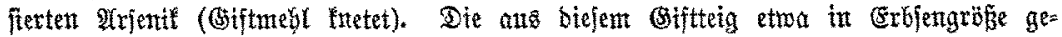

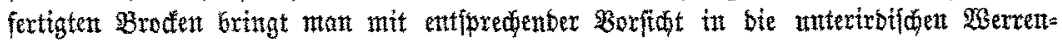
gä̆tge - ber Grfolg jei ein fehre rofiber.

\section{Die forfltide bodjhule 2lihaffenburg.}

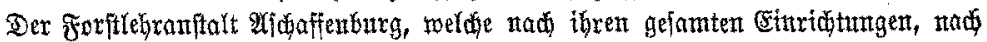

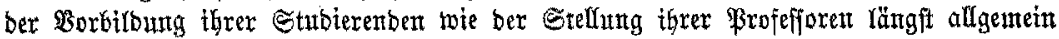

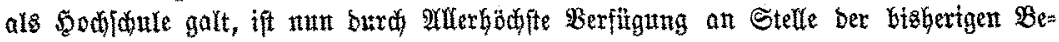

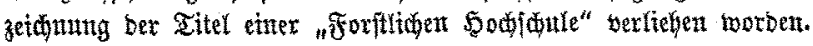

\section{Don der Godfidqule für Bodenfultur in wien.}

शra Reftor fitr bas Stubienjahr $1898 / 99$ wurbe ber orb. Frofeffor ber Fonft=

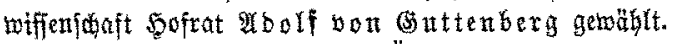

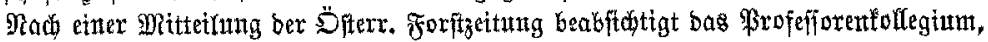

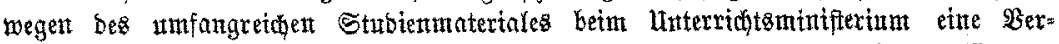

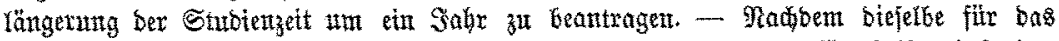

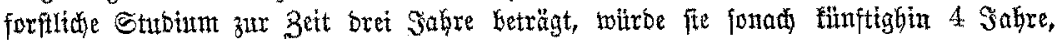
twie int Bayen, umfaffen.

\section{Beriditigung.}

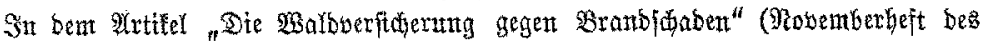

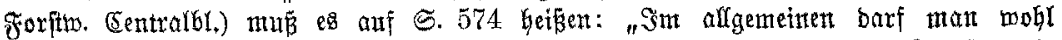

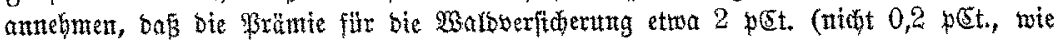
bort irrtitmlth gebuct) bom Ertrag betragent barf,

Rauterbad in Sberheffer. 